\title{
Binding capacity of rat liver glucocorticoid receptor in different periods after single neonatal benzpyrene treatment (imprinting)
}

\author{
G. Csaba, Ágnes Inczefi-Gonda \\ Department of Genetics, Cell- and Immunobiology, Semmelweis University, Budapest, Hungary \\ Received: May 7, 2001 \\ Accepted: September 9, 2001
}

Newborn rats of both sexes were treated (imprinted) with $20 \mu \mathrm{g}$ of benzpyrene. Two hours, 2 days, 1, 2, 3 weeks, 1 month and 2 months after imprinting the liver glucocorticoid receptors were studied for binding of dexamethasone. Two-hour and 2-day values were not appreciable. One week after treatment the receptor's affinity was extremely low both in control and treated treated animals. Two weeks after imprinting a significant difference in density (lower) and affinity (higher) was observed between the male treated and control animals. At 3 weeks and one month the binding capacity of treated and control animals was equal however, at 2 months $\mathrm{B}_{\max }$ of males increased and that of females decreased significantly in the neonatally benzpyrene treated animals. This means that for the development of perinatal imprinting effect a long time is needed, and the effect is manifested after a period of lability.

Keywords: hormonal imprinting, benzpyrene, glucocorticoid receptor, newborn, liver

At the perinatal critical period when the hormone receptor meets the target hormone the first time, hormonal imprinting develops, which is needed for the completion of receptor maturation and the normal response of the cell $(4,5)$. However, in the presence of excess amount of the target hormone or molecules, similar to it (members of the same hormone family, synthetic analogues, drugs or environmental pollutants with similar structure, etc.) faulty imprinting develops $(6,7)$ causing the abnormal binding capacity and disparate response of the cell for life, which is manifested in the morphology and biochemical characteristics of the organs studied as well as in the (sexual) behavior of the animals $(2,3,8,11,16,18,19)$. Even some

Correspondence should be addressed to

Prof. G. Csaba

Department of Genetics, Cell- and Immunobiology

Semmelweis University

H-1445 Budapest, P.O. Box 370, Hungary 
genetic alterations occur (10). Some of these alterations can be manifested in case of peptide, amino acid or steroid type hormones alike (7). Nevertheless, the time of the effect of imprinting is not known, therefore it is not easy to find the proper time for the first demostration of the altered binding capacity of the receptors. As benzpyrene was one of the "best" foreign molecules which provoked faulty imprinting of steroid receptors, in the present experiments we studied the binding capacity of liver glucocorticoid receptors in different time points after imprinting with a single neonatal benzpyrene treatment.

\section{Materials and Methods}

Newborn (before $24 \mathrm{~h}$ after birth) Wistar rats of both sexes of our closed breed were used in the experiments. The animals were treated with $20 \mu \mathrm{g} / \mathrm{animal}$ benzpyrene (Sigma, USA). Livers of the animals were removed in ether narcosis for receptor kinetic analysis 2 hours, 2 days, 1, 2 and 3 weeks, 1 and 2 months after benzpyrene treatment. For the measurements pooled liver homogenates were used up to 2 weeks of life, later on individual livers were studied. Each measurement was done in duplicate and the experiments were repeated at least three times.

\section{Preparation of cytosol fractions}

All procedures were performed at ice/water temperature. Tissues $(1.5 \mathrm{ml} / \mathrm{g}$ wet weight) were cut into pieces and homogenized in Tris-HCl buffer containing $1.5 \mathrm{mM}$ EDTA (pH 7.4), freshly supplemented with $20 \mathrm{mM}$ molybdate and $2 \mathrm{mM}$ dithiotreitol, with a motor-driven glass-teflon Potter homogenizer. Homogenates were centrifuged at $100,000 \mathrm{~g}$ for $60 \mathrm{~min}$ at $4{ }^{\circ} \mathrm{C}$ and the supernatants were used for receptor assays. Protein content was estimated by the Coomassie blue method.

\section{Glucocorticoid receptor assay for liver cytosol}

Five hundred micrograms of protein was incubated with 10, 5, 2.5, 1.25, 0.6, 0.3 and $0.15 \mathrm{nM}{ }^{3} \mathrm{H}$-dexamethasone (Amersham, Buckinghamshire, UK; spec. act. $1.8 \mathrm{TBq} / \mathrm{mmol}$ ) in the absence or presence of 1000 -fold molar excess of unlabeled ligand (dexamethasone, Sigma, Mo. USA) in a total volume of $100 \mu \mathrm{l}$ at $0{ }^{\circ} \mathrm{C}$ for $18 \mathrm{~h}$. Bound glucocorticoid was separated by the charcoal method and counted in OptiPhase, HiSafe (Pharmacia, Lund, Sweden, 35\% efficiency). Radioactivity measured in the presence of 1000-fold molar excess of unlabeled ligand was regarded as nonspecific binding. 


\section{Analysis of the results}

They were carried out by the computer program EBDA and LIGAND written by McPherson $(13,14)$; EBDA was used to process raw data. Ligand (non-linear curve fitting program) was used to obtain final parameter estimates, on the basis of Scatchard analysis. Statistical analysis of final parameters was calculated by the computer program DATAANALYSIS, v.1.0 (analysis of variance, simple F-test comparison).

\section{Results and Discussion}

In the livers removed 2 hours or two days after benzpyrene treatment the receptor binding values of treated animals were so confused that the computer program was not able to evaluate them. This points either to the strong effect of the treatment, or the slow elimination of the benzpyrene. One week after treatment there were very high $K_{d}$ values, which shows low affinity of receptors. In that time there was no difference in the density of receptors of control and treated animals (Tables I and II) independently of their sexes. However, at two weeks in male animals, significant difference was observed both in $\mathrm{B}_{\max }$ and $\mathrm{K}_{\mathrm{d}}$. At the same time there was no difference between female control and treated animals. At three weeks and 1 month the values of both sexes were similar in case of control and treated ones. At two months the density of receptors significantly increased in males and decreased in females, without any significant differences in $\mathrm{K}_{\mathrm{d}}$.

The binding capacity of liver glucocorticoid receptors develops slowly. The number of binding sites are low at fetal age and begin to increase after birth $(1,17)$. Hormonal imprinting influences the receptors during that time (7). In earlier experiments the failure of receptors, caused by imprinting was measured in adolescent or adult age and its effect was always found, as was found also in the present experiment.

Table I

Dexamethasone binding capacity ( $B_{\max }$ and $K_{d}$ values, $10^{-9} \mathrm{M}$ ) of male rat liver at different points of time after single neonatal benzpyrene imprinting

\begin{tabular}{lccrc}
\hline \multicolumn{1}{c}{ Time } & Control $\mathrm{B}_{\max }$ & \multicolumn{1}{c}{ Benzp. $\mathrm{B}_{\max }$} & \multicolumn{1}{c}{ Control $\mathrm{K}_{\mathrm{d}}$} & ${\text { Benzp. } \mathrm{K}_{\mathrm{d}}}$ \\
\hline 1 week & $4.12 \pm 0.12$ & $4.3 \pm 1.54$ & $23.0 \pm 6.59$ & $11.4 \pm 0.07$ \\
2 weeks & $5.31 \pm 0.54$ & $\mathbf{3 . 2 0} \pm 0.98^{*}$ & $11.83 \pm 2.13$ & $\mathbf{4 . 1 0} \pm 2.15^{* *}$ \\
3 weeks & $1.73 \pm 0.44$ & $1.93 \pm 0.62$ & $3.03 \pm 0.83$ & $4.03 \pm 1.07$ \\
1 month & $1.73 \pm 0.72$ & $1.91 \pm 0.91$ & $3.67 \pm 0.83$ & $4.51 \pm 1.90$ \\
2 months & $2.95 \pm 0.12$ & $\mathbf{3 . 6 7} \pm 0.07^{* *}$ & $6.92 \pm 1.06$ & $8.63 \pm 1.90$ \\
\hline
\end{tabular}

$*=\mathrm{p}<0.05, * *=\mathrm{p}<0.02$ 
Table II

Dexamethasone binding capacity $\left(B_{\max }\right.$ and $K_{d}$ values, $\left.10^{-9} \mathrm{M}\right)$ of female rat liver at different points of time after single neonatal benzpyrene imprinting

\begin{tabular}{lllcr}
\hline \multicolumn{1}{c}{ Time } & Control $\mathrm{B}_{\max }$ & Benzp. $\mathrm{B}_{\max }$ & ${\text { Control } \mathrm{K}_{\mathrm{d}}}$ & Benzp. $\mathrm{K}_{\mathrm{d}}$ \\
\hline 1 week & $2.38 \pm 1.7$ & $3.65 \pm 0.29$ & $11.34 \pm 10.33$ & $10.84 \pm 8.90$ \\
2 weeks & $3.30 \pm 0.45$ & $3.36 \pm 0.54$ & $4.55 \pm 1.11$ & $4.02 \pm 0.31$ \\
3 weeks & $2.22 \pm 0.29$ & $2.05 \pm 0.1$ & $3.89 \pm 0.15$ & $4.93 \pm 0.44$ \\
1 month & $1.41 \pm 0.59$ & $1.88 \pm 0.78$ & $3.22 \pm 0.2$ & $5.12 \pm 1.22$ \\
2 months & $1.87 \pm 0.06$ & $\mathbf{1 . 4 3} \pm 0.23 *$ & $6.03 \pm 0.32$ & $5.79 \pm 0.11$ \\
\hline
\end{tabular}

$*=\mathrm{p}<0.05$

However, the results mentioned above have demonstrated that time is needed for the manifestation of the effect of imprinting and this is about two months in case of liver glucocorticoid receptors. Nevertheless, on the basis of the present experiments, the significant appearance of imprinting effect in the 2-week specimens, and its disappearance at 3 weeks and one month is hard to explain. The signs of lability could be observed also before 2 weeks, manifested in the confusion of results at 2 hours and two days as well, as in the low affinity at one week. The unmaturity of receptors in this period is expressed in the control animals, too, represented by the high $\mathrm{K}_{\mathrm{d}}$ values in them. However, from the third week there is a "calm" period of receptor binding and this is disturbed by the effect of imprinting in both sexes at the second month.

The other problem is that at two weeks, only the male animals produced significant differences from the control under the effect of imprinting, and at two months, when the direction of the effect was opposite. However, there are differences in the maturation of male and female steroid receptors, which can explain this phenomenon (15), and especially in the case of benzpyrene imprinting, when single neonatal treatment caused a $35 \%$ elevation of receptor number in adult males, without any change in females (9), or differences were found concerning sexual behavior depending on the sex (8). These differences are in close connection with the disparate microsomal enzyme systems of males and females (12).

The main conclusion of the experiment is that after a period of lability the imprinting is stabilized around two months of age. However, this is valid only to the glucocorticoid receptors of the liver, as there are data on the tissue to tissue differences in the ontogeny of glucocorticoid receptors (17) and this cannot remain without influence to the effect of imprinting. 


\section{Acknowledgements}

This work was supported by the National Research Fund (OTKA- T-029002), Hungary. The authors thank for the expert technical work of Ms. Katy Kallay.

\section{REFERENCES}

1. Andrews GK: Glucocorticoid receptors in murine visceral yolk sac and liver during development. J. Steroid Biochem. 23, 437-443 (1985)

2. Arriaza CA, Mena MA, Tchernitchin AE: Prenatal androgenisation selectively modifies some response to oestrogens in the prepubertal rat uterus. J. Endocrinol. 120, 379-384 (1989)

3. Bern HA, Jones LA, Mori T, Young PN: Exposure of neonatal mice to steroids: long term effects on the mammary gland and other reproductive structures. J. Steroid Biochem. 6, 673-676 (1975)

4. Csaba G: Phylogeny and ontogeny of hormone receptors: the selection theory of receptor formation and hormonal imprinting. Biol. Rev. 55, 47-63 (1980)

5. Csaba G: Receptor ontogeny and hormonal imprinting. Experientia 42, 750-759 (1986)

6. Csaba G: Phylogeny and ontogeny of chemical signaling: origin and development of hormone receptors. Int. Rev. Cytol. 155, 1-48 (1994)

7. Csaba G: Hormonal imprinting: its role during the evolution and development of hormones and receptors. Cell Biol. Internat. 24, 407-414 (2000)

8. Csaba G, Karabélyos Cs, Dalló J: Fetal and neonatal action of a polycyclic hydrocarbon (benzpyrene) or a synthetic steroid hormone (allylestrenol) as reflected by the sexual behavior of adult rats. Life Sci. 63, PL101-105 (1991)

9. Fujita I, Sindhu RK, Kikkawa Y: Hepatic cytochrome P450 enzyme imprinting in adult rat by neonatal benzo(a) pyrene administration. Pediatr. Res. 37, 646-651 (1995)

10. Gray-Nelson K, Sakay I, Eitzman B, Steel T, McLachlan JA: Exposure to diethylstilbestrol during a critical developmental period of the mouse reproductive tract leads to persistent induction of two estrogen regulated genes. Cell Growth Diff. 5, 595-606 (1994)

11. Iguchi T: Cellular effect of early exposure to sex hormones and antihormones. Int. Rev. Cytol. 139, 1-57 (1992)

12. Lamartiniere CA, Nicholas $\mathrm{JN}$ : Neonatal chlordecone alteration of the ontogeny of sex-differentiated hepatic drug and xenobiotic metabolizing enzymes. Biochem. Pharmacol. 33, 4092-4095 (1981)

13. McPherson GA: Analysis of radioligand binding experiments and a microcomputing system. Trends Pharmacol. 41, 369-370 (1983)

14. McPherson GA: Analysis of radioligand binding experiments: A collection of computer programs to the IBM PC. J. Pharm. Meth. 14, 213-228 (1985)

15. Martin R, al-Sheibani AH, Gottschalk J, Martin H, Rotzsch W: Age dependent changes in signal transduction of glucocorticoid hormones after physiological stress in liver cells of male Wistar rats. Z. Gerontol. 27, 194-199 (1994)

16. Newbold RR, Jefferson WN, Padilla-Burgos E, Bullock BC: Uterine carcinoma in mice treated neonatally with tamoxifen. Carcinogenesis 18, 2293-2298 (1997)

17. Ohsawa N: Regulation of hormone receptor. Fol. Endocrin. Jap. 53, 1368-1378 (1977)

18. Sato T, Chiba A, Okamura H, Ohta Y, Takasugu N, Iguchi T: Induction of estrogen receptor and cell division in genital tract of male mice by neonatal exposure of diethylstilbestrol. Reprod. Toxicol. 8, 145-153 (1994)

19. Tchernitchin AN, Tchernitchin N: Imprinting of paths of heterodifferentiation by prenatal or neonatal exposure to hormones, pharmaceuticals, pollutants and other agents and conditions. Med. Sci. Res. 20, 391-397 (1992) 